\title{
14
}

\section{POWER STATIONS AND PETROLEUM HERITAGE IN ITALY}

\author{
The Case of Porto Tolle
}

\section{Chiara Geroldi and Gloria Pessina}

In Italy, as in other parts of the world, thermoelectric power plants fueled by oil are being decommissioned and transformed, raising questions about the materiality of the energy transition and the role of power stations in the global petroleumscape. Making good decisions about what to do with these plants and the surrounding areas requires research on the historical emergence of this petroleum-related infrastructure as well as its location, spatial form, and connection to ports and consumption sites. We began to see the need for the research we present here while participating in a consultancy undertaken by the Politecnico di Milano ${ }^{1}$ for Enel, a formerly state-run energy company founded in 1962, privatized in 1999, and now a multinational energy company. With its Futur-e project, launched in 2015, Enel asked Politecnico di Milano to analyze the territories of ten power stations (out of twenty-three undergoing closure) in order to provide information to participants in competitions for designers (e.g., in a call for ideas) as well as to entrepreneurs who might be interested in acquiring and redeveloping the sites. ${ }^{2}$

Intrigued by the material we collected during the consultancy and visits to several power plants undergoing closure, we started the research presented in this chapter. Through the lens of the literature on the global petroleumscape, we began analyzing several oil-fueled power plants as elements that direct and redirect flows. Afterward, we decided to focus on a particularly interesting case, the power station of Porto Tolle, showing its role in the global petroleumscape and highlighting the specific historical, geographical, environmental, and sociopolitical factors that characterize its territory and may influence its post-oil future. Our research seeks to fill a gap in the design and planning literature, in which the landscape of (oil-fueled) thermoelectric power stations is little explored, thus offering a necessary addition to the emerging research on the petroleumscape. ${ }^{3}$

\section{Power Stations in Remote Areas as Part of the Global Petroleumscape}

The power stations involved in the Futur-e project are spread out across Italy and vary in size, from only a few hectares to over 100 ha. Most are located in marginal sites, often near the 
sea, and far from major urban centers. A few are located in ports or industrial areas. The large oil-fueled power station of Porto Tolle, which once produced 10 percent of Italy's energy, lies in the particularly remote and fragile territory of the Po River delta. It closed in 2015.

Although not physically close to cities, power stations such as Porto Tolle can be considered "urban" using the concept of planetary urbanization proposed by Neil Brenner and Christian Schmid. ${ }^{4}$ In particular, they can be considered part of extended urbanization or what Brenner defines as an "operational landscape." Brenner and Schmid argue that spaces usually considered part of the "non-urban realm," such as infrastructures, pipelines, "nature parks" as well as oceans, deserts, or even the atmosphere, have now become part of "the worldwide urban fabric." 6 The global petroleumscape is a perfect expression of planetary urbanization, as it connects places of extraction, often located in areas difficult to reach, with consumers, who are mainly located in agglomerations. Brenner further develops the concept of planetary urbanization, stressing that urbanization contains both concentration and extension and noting that urban theory has focused its attention primarily on processes of concentration, ${ }^{7}$ ignoring the wider areas and sites that support these processes, such as oil production sites or power stations. Agglomerations must be connected to large-scale processes of territorial reorganization and resource extraction that encompass the world. ${ }^{8}$

Porto Tolle power station lies in the protected area of the Po River delta, which in 2015 was recognized as a Biosphere Reserve within the UNESCO Man and Biosphere Programme. Although the plant might appear remote, it was once tightly connected to global flows of oil and national flows of electrical energy serving residential and industrial areas. As such, the power plant can be seen as part of the urban, being an "operational landscape" that supports agglomerations through energy production. Such a remote site also exemplifies important transformations, particularly those related to the energy sector at the Italian national level and current European policies for energy transition. Our analysis of this site reveals the large landscape of oil to which the power station is connected and identifies the oil-related elements in this and other oil-fueled power stations in the Futur-e project.

\section{Global Landscapes of Oil, Architecture, and Heritage}

As Carola Hein writes, even though "the development of petroleum-based technologies and infrastructure has produced significant changes in the built environment," 9 such oil-related changes in cities and landscape have been largely ignored by architecture and urban studies. Various approaches to oil have been promoted in other disciplines, including political ecology, energy humanities, economic geography, planning history, cultural history, and the history of the built environment. ${ }^{10}$

Studies in the field of political ecology were among the first attempts to highlight the contradictions and conflicts emerging in the territories where oil is extracted and energy is produced. ${ }^{11}$ Moreover, political ecology scholars started analyzing elements through which oil circulates, ${ }^{12}$ how oil is embedded in sociopolitical relations and how it affects territories. ${ }^{13}$ Concerned with the materiality of oil and building on previous studies on the flows of various types of "matter" (e.g., water, waste, fuels) in the field of political ecology, ${ }^{14}$ Gavin Bridge lists both the specific "biophysical characteristics" and the "material forms of oil," identifying three types of extractive spaces: (1) a "geography of holes" such as a mine shaft or an oil well, (2) the structures that drive the flows of fuels, and (3) waste and waste spaces produced from extractive industries. ${ }^{15}$

While such approaches unveiled the complexity of oil-affected areas, with an in-depth overview of the interrelations between matter, space, power, and society, the landscape of lines, axes, 
and nodes was merely listed and localized by early political ecology scholars, who aimed at identifying emerging environmental conflicts, unequal exposure to possible sources of pollution, and imbalances of power. Architects, designers, and planners have been contributing to the debate on the global petroleumscape through an in-depth analysis of the material forms of spaces, attempting to identify which parts of the landscapes of oil could be kept as heritage and how they could be reimagined for future uses. ${ }^{16}$ After having studied the topic for the past decade, ${ }^{17}$ Hein has introduced the concept of a "palimpsestic global petroleumscape," which includes the physical forms of the built environment, its representations and values as well as its uses. ${ }^{18}$

Moreover, Hein emphasized that oil networks are "powerful producers of new landscape" and that the global oil industries have generated an "international 'landscape of oil," which also influences our understanding of territories and movements. ${ }^{19}$ Building on this literature, this chapter considers the landscapes in which oil is transformed into electricity, highlighting flows of oil, connected infrastructure, emerging conflicts as well as related architectural elements. While extensive work has been conducted on the conflicts as well as the flows of matter and power related to sites of electricity generation, especially nuclear power stations ${ }^{20}$ and hydropower, ${ }^{21}$ less has been written on thermoelectric power plants in terms of conflicts and flows ${ }^{22}$ as well as of landscape and built environment. ${ }^{23}$ Therefore, we introduce the topic of the contemporary landscapes of oil and electricity in Italy as an addition to the existing international literature on the petroleumscape and on the political ecology of energy. Then, we focus on a specific plant and the surrounding territory to show how an in-depth description of the spaces of the petroleumscape can be used to identify valuable elements for post-oil landscapes.

\section{Contemporary Landscapes of Oil and Electricity in Italy: Four Examples}

In the global context of the energy transition, Italy is adopting international policies aimed at reducing the use of fossil fuels for energy production. In 2015, when Enel launched the Futur-e project for twenty-three thermoelectric plants with a significant total gross capacity of $13 \mathrm{GW}$, the company explained that these large plants running on fossil fuels have become marginal in Italian electricity production, due to diminishing industrial demand ${ }^{24}$ and an increase in small renewable energy plants throughout the territory. ${ }^{25}$ The production capacity of Italian thermoelectric plants now exceeds demand. ${ }^{26}$ Several architectural and other elements of thermoelectric power station landscapes - physical structures that may remain after the energy transition — can be interpreted as the heritage of the future and as objects with the potential for new uses.

In what follows, we analyze four oil-fueled power stations showing the variety of oil networks in which the power stations were located: Porto Tolle, Montalto di Castro, Rossano, and Bari. Emphasizing the materiality and the diverse environments of the stations, we explain the various ways oil can reach the power stations and explain how oil-fueled power stations can be reconverted to other fuels. Calls for a manifestation of interest in buying and redeveloping them have been made for all four stations. At the time of writing (2020), the most advanced in the transformation process was Porto Tolle, for which a preliminary sale agreement has been signed. Three of the plants-Porto Tolle, Montalto di Castro, and Rossano-are located quite far from major urban centers in agricultural areas, in the north, center, and south of Italy, respectively. They face the sea and use sea water for plant cooling (Porto Tolle drew water from both the sea and the Po River). The Bari station is located in the city of Bari, in a transition zone between the city center and an industrial area, adjacent to the dismantled Stanic oil refinery (owned by the Eni oil and gas company). These sites have not yet been sold and their regeneration has not started yet. 
The sites vary in terms of size and gross capacity: Porto Tolle occupies 380 ha and had a gross capacity of 2.640 MW; Montalto di Castro extends over 220 ha and had a gross capacity of 3.600 MW; Rossano occupies 50 ha with a gross capacity of $1.738 \mathrm{MW}$, while Bari extends over 6.8 ha and had a gross capacity of $205 \mathrm{MW}$. Some power stations were fueled by oil throughout their life span, while others underwent conversions or exploited both oil and gas (Figure 14.1). Porto Tolle has been always fueled by oil; its four steam-powered electric sections began operating between 1980 and 1984. Enel proposed a conversion to coal in 2005, but Italy's Ministry of the Environment, Land, and Sea ultimately rejected it in 2013. The thermoelectric plant of Rossano began operating in the mid-1970s. At first, it was fueled by oil; later, gas was preferred as it was considered to have less of an impact on nearby agricultural fields. ${ }^{27}$ In the mid-1990s, Enel added several turbogas repowering units, which are fueled by gas. The Bari plant, constructed in the late 1950s, was initially powered by coal, later by natural gas and oil, and after 2008, exclusively by natural gas. In the late 1970s, a nuclear power station was partially constructed on the Montalto di Castro site, but it never became operational due to the 1987 referendum rejecting nuclear power across Italy. In the 1990s, Enel constructed eight turbogas groups and a thermoelectric plant at the site, fueled by oil and gas. ${ }^{28}$

Oil reached these power stations in various ways, after long journeys involving global systems of infrastructure and logistics that transport oil from extraction sites to power stations, which converted the oil to electrical energy. The Porto Tolle power station received oil mainly from a pipeline of $92 \mathrm{~km}$, which started at a depot in the industrial area of the port of Ravenna. The station of Montalto di Castro was serviced by a $35 \mathrm{~km}$ oil pipeline in the sea, starting at the Enel power plant of Torrevaldaliga Nord, near the port of Civitavecchia in the metropolitan area of Rome. The Torrevaldaliga Nord plant obtains oil from a pipeline of ca. $3 \mathrm{~km}$ extending from a single point mooring tower in the sea. ${ }^{29}$ The Rossano plant had its oil delivered by tanker trucks coming from the depots of Taranto and Crotone, at a distance of

POWER STATIONS OF THE ENEL FUTUR-E PROJECT AND FUELS

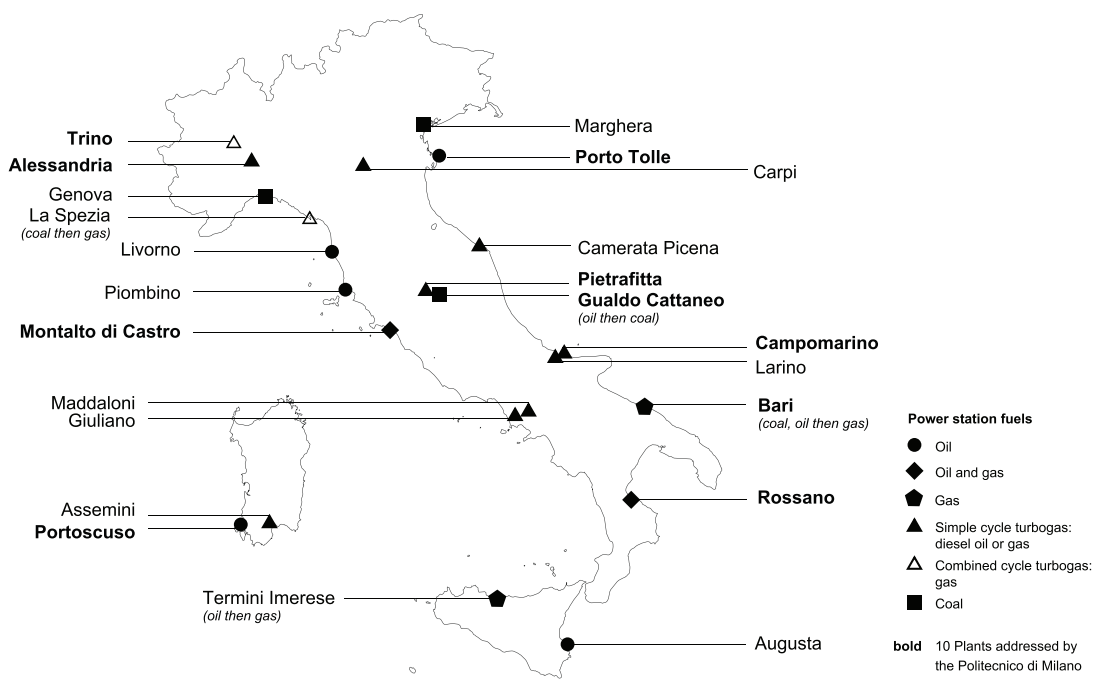

FIGURE 14.1 Thermoelectric power stations involved in the Enel Futur-e project. Sources: Chiara Geroldi and Enel S.p.A. 
150 and $95 \mathrm{~km}$, respectively. ${ }^{30}$ Enel had planned an oil pipeline to connect the Rossano plant to the nearby port of Corigliano Calabro, but this project was highly contested and never implemented. Some oil was also delivered from this port via tanker trucks (Figure 14.2). ${ }^{31}$

This brief look at oil flows within the Italian territory reveals connections between oilfueled power stations and the port areas, where oil is delivered and where refineries and oil depots are often present. The pipelines connecting some power stations are not just "lines"; indeed, they are often a source of conflict. As an alternative or in addition to pipelines, oil was also carried by tanker trucks, or in the case of Porto Tolle, also by barges. An even broader view of flows of oil shows the high connectivity of these power stations on a global scale. Although these plants are quite disconnected from their immediate surroundings, they are highly connected to a global network of fuel flows, in addition to the Italian energy network.

Although each plant has some unique features, there are many common elements. Thermoelectric plants have large machinery halls, high chimneys, and other features that depend on the type of fuel used (coal, oil, oil and gas, or gas alone) such as coal yards, oil tanks, oil pipelines, and methane pipelines. The ones located far from major water sources also contain cooling towers. Turbogas simple-cycle plants (also involved in the Futur-e project) are very different and much smaller as they are meant to operate only during periods of high demand or emergencies. $^{32}$ They were fueled by diesel oil or gas and served by tanker trucks and methane pipelines. All the power stations in the Futur-e project are equipped with oil tanks or they have them in their proximity, an example of thermoelectric plants' connection to the petroleumscape. Oil tanks vary in terms of number (e.g., from two in turbogas plants to nine at Porto Tolle), dimension (e.g., from 7,500 to $20,000 \mathrm{~m}^{3}$ at Bari and from 50,000 to $100,000 \mathrm{~m}^{3}$ at Porto Tolle and

OIL PIPELINE SYSTEM IN ITALY AND THE FOUR POWER STATIONS ADDRESSED

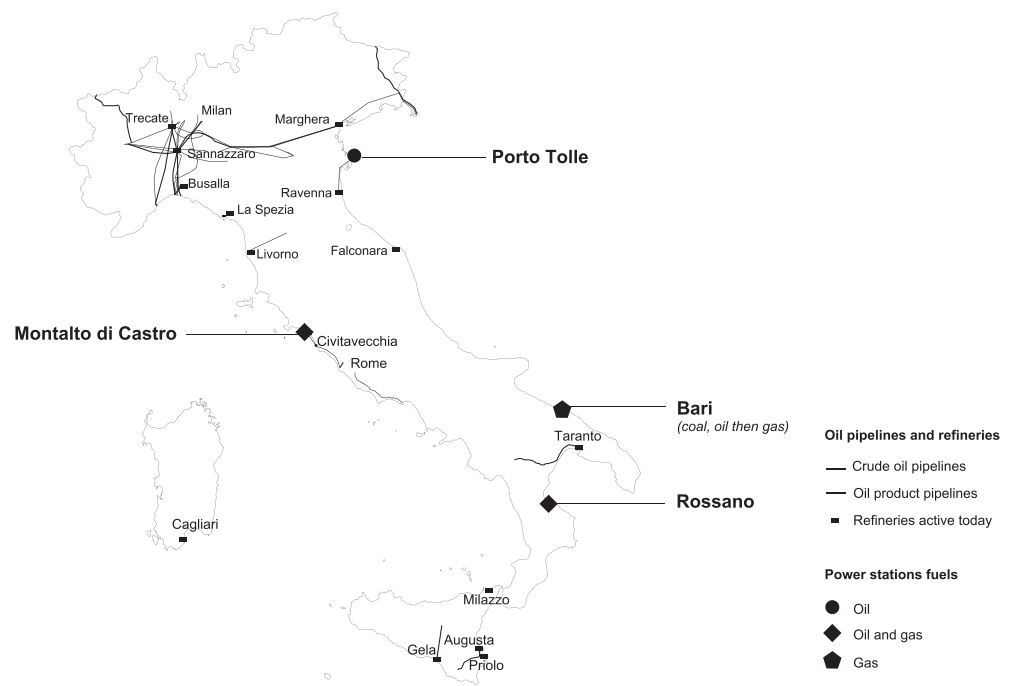

FIGURE 14.2 Oil pipelines, active refineries, and the power stations of Porto Tolle, Montalto di Castro, Rossano, and Bari. Source: Chiara Geroldi. Pipelines base map information: (C) PLATTS for the underlying grids for electricity, gas, and oil, 2016 (C) European Union, 2019. 
Montalto di Castro), and total area occupied. They are surrounded by earth embankments or by concrete walls that create basins to contain oil in case of leaks.

From a design reuse perspective, several elements of the plants are of interest, including the large and impressive machinery halls, the high chimneys that serve as local landmarks,

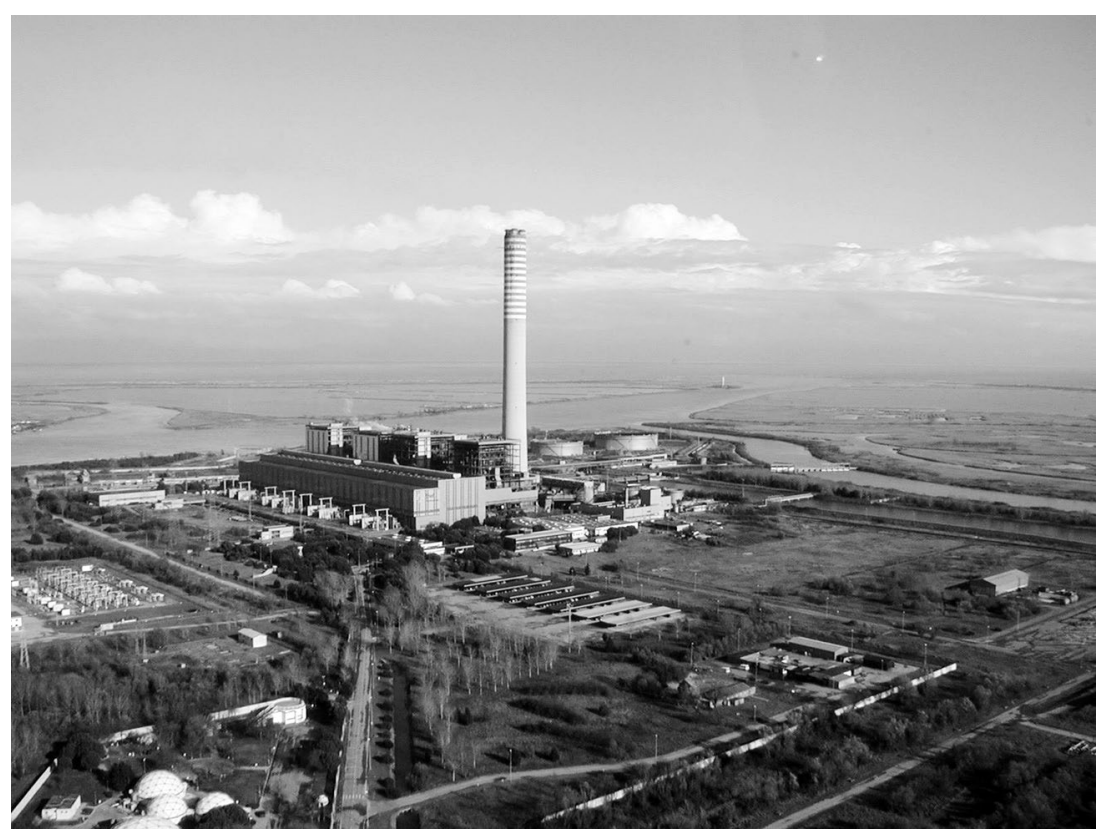

FIGURE 14.3 The power station of Porto Tolle, located in the Po River delta. Source: Enel Produzione S.p.A.

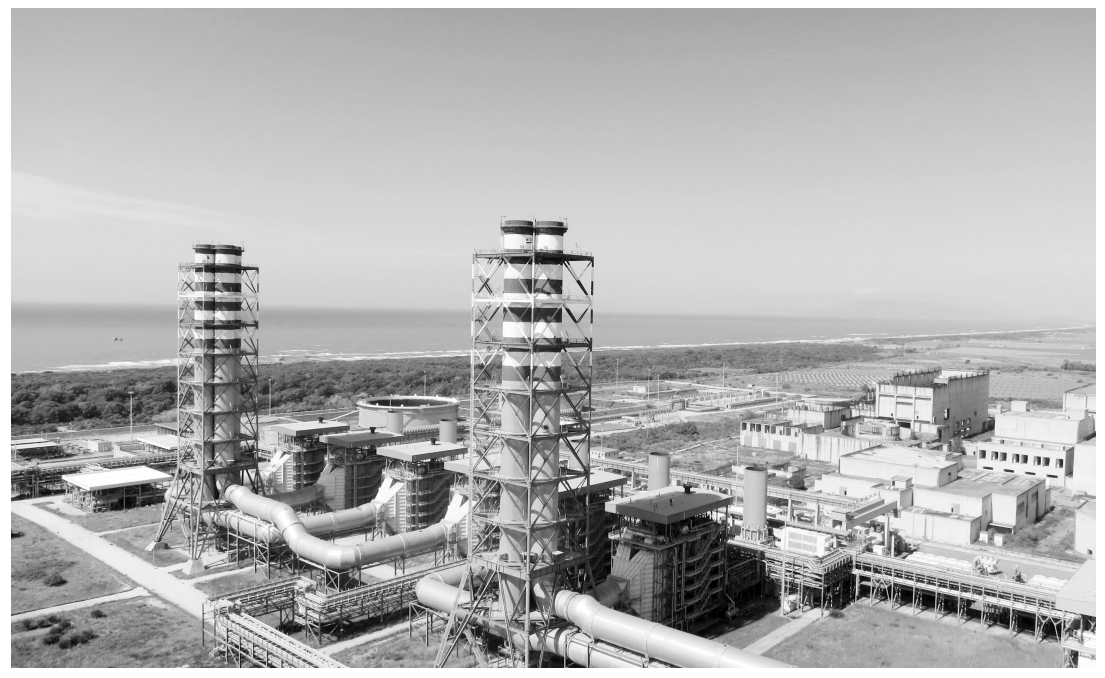

FIGURE 14.4 The power station of Montalto di Castro, located in a former Etruscan territory on the Tyrrhenian Sea. Source: Enel Produzione S.p.A. 
the hyperbolic cooling towers, and the oil tanks. ${ }^{33}$ Specific elements of the power stations' context, environments, and history can also be particularly relevant in terms of "heritage" to be enhanced. Montalto di Castro, for instance, contains large and thick unused concrete structures intended for the nuclear plant and Etruscan tombs (the site is in a former Etruscan territory). A wide strip of protected Mediterranean landscape is located along its border, close to the beach. Rossano, which has a particularly luminous machinery hall, is located in front of the beach and has olive trees on the property. Porto Tolle, which is particularly large, includes fragile environments, rich in biodiversity, both on land and in the water, typical of the Po River delta (Figures 14.3-14.6).

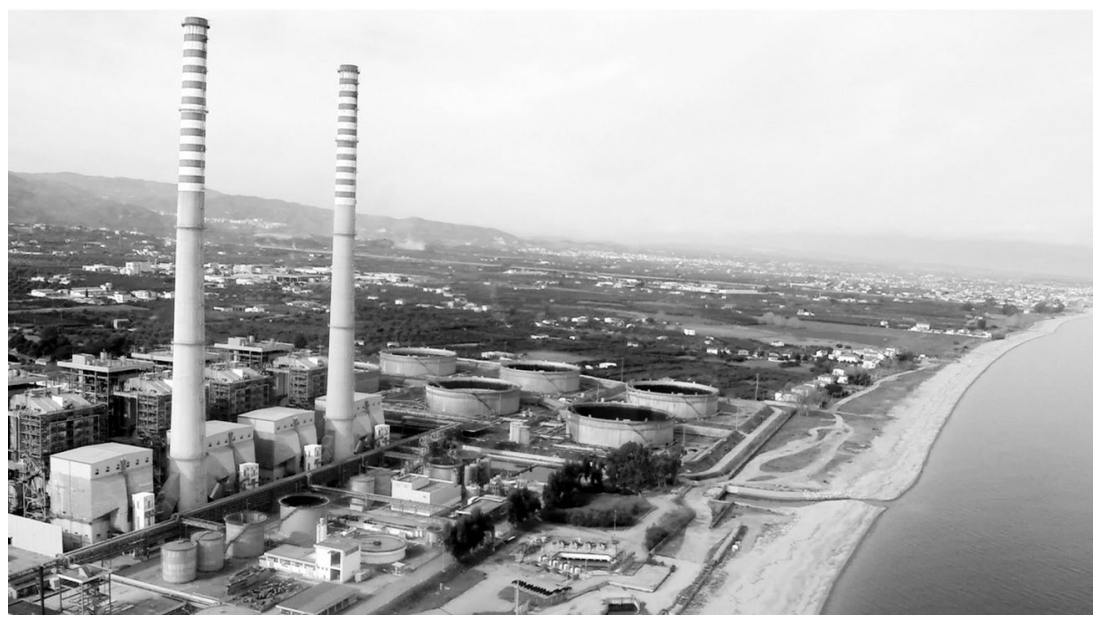

FIGURE 14.5 The power station of Rossano, located on the Ionian Sea. Source: Enel Produzione S.p.A.

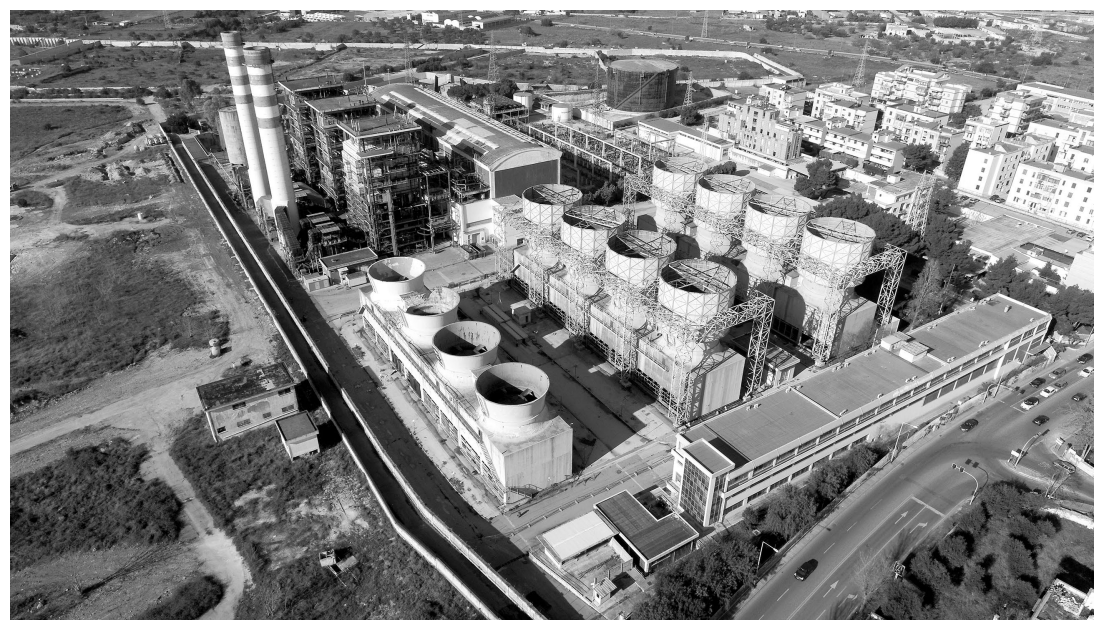

FIGURE 14.6 The power station of Bari, located close to the dismantled Stanic Refinery. Source: Enel Produzione S.p.A. 


\section{The Po River Delta: A Fragile Equilibrium Between Land, Water, Oil, and Gas}

The Porto Tolle power station is located in the territory of Polesine, part of the Po River delta in the Veneto region (Figures 14.7-14.8). Geographers and geologists have highlighted rare features of the area that result from the accumulation of centuries of detritus from the rivers Adige and Po. ${ }^{34}$ Our description of the context elaborates on the existing literature on the territorial and environmental fragility ${ }^{35}$ of the Po River delta ${ }^{36}$ produced by a wide range of disciplines, including geology, geography, sociology, and urban, rural, and heritage studies.

Human interventions, climatic and alluvial factors have been shaping the Po River delta throughout its history, and since the end of the 1880s, large-scale drainage works were promoted by land reclamation consortia. ${ }^{37}$ Despite many attempts to control the water, several

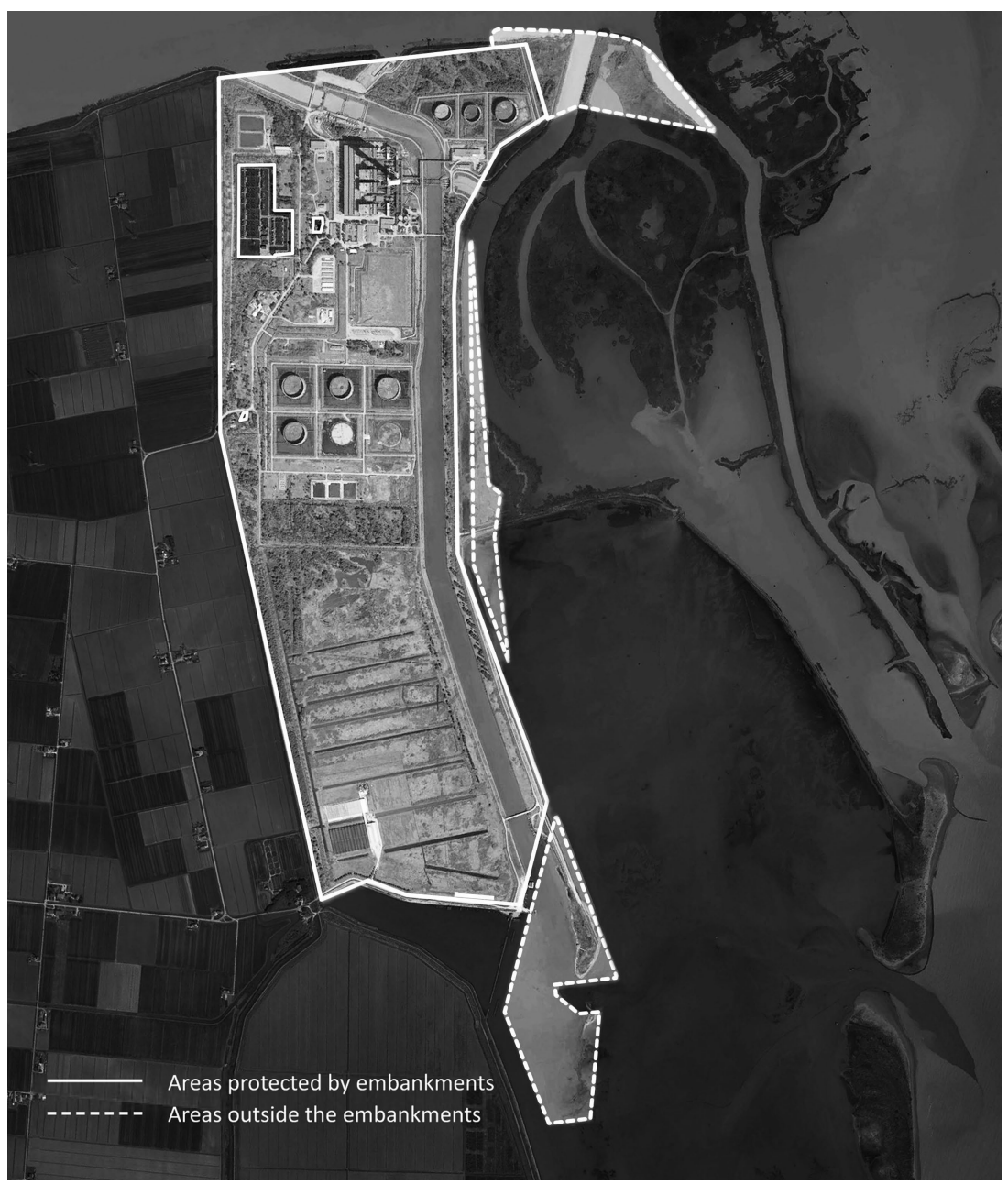

FIGURE 14.7 The power station of Porto Tolle. Source: Google Earth. Image (C) 2016 TerraMetrics Data SIO, NOAA, US Navy, NGA, GEBCO modified by the authors. 


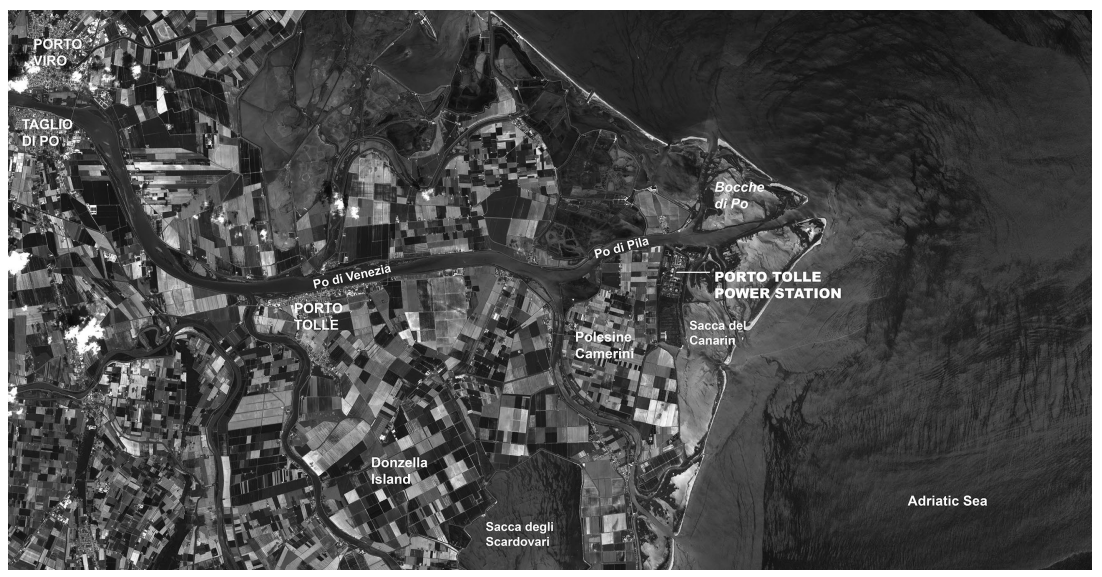

FIGURE 14.8 The power station of Porto Tolle in the context of Polesine (Po River delta). Source: Contains modified Copernicus Sentinel data (2020) (texts added by the authors).

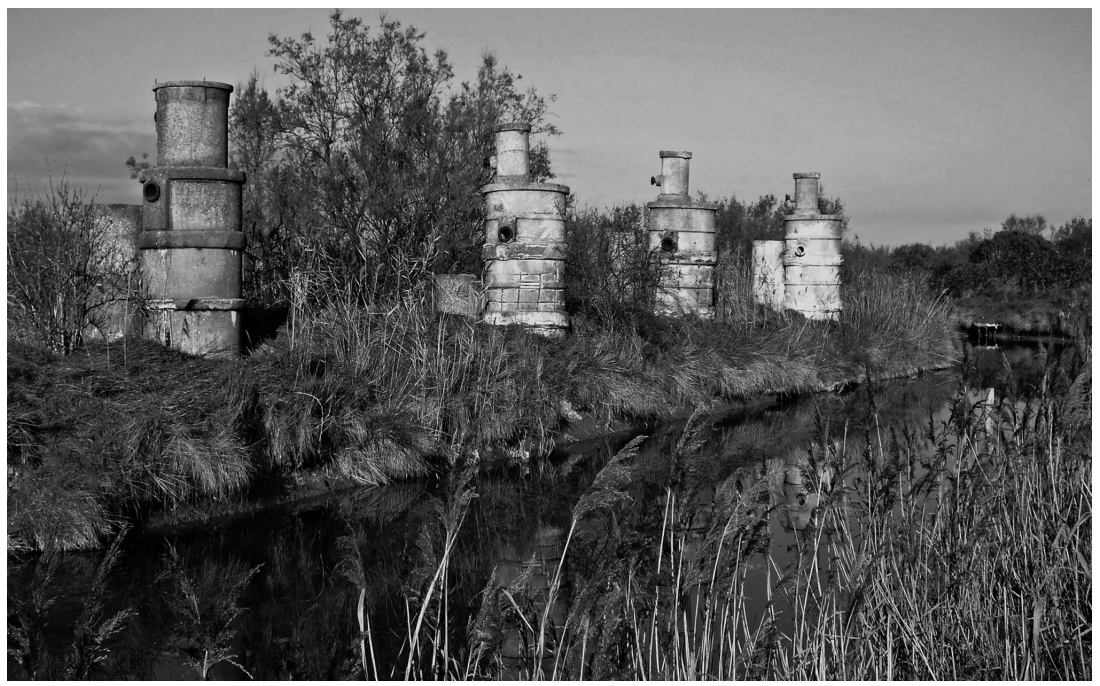

FIGURE 14.9 Abandoned methane gas extraction wells in Ca' Pisani (Porto Viro, RO). Source: Moreno Bonifacio.

tragic inundations have occurred in Polesine. According to geologists, ${ }^{38}$ the frequency and the severity of the floods increased between the late 1930s and early 1960s, due to the extraction of underground water rich in methane gas (Figure 14.9), which accelerated land subsidence in the area. ${ }^{39}$ In 1951 and 1966, two major floods devastated Polesine, causing the deaths of several hundred people and destroying thousands of properties.

The relative poverty of the area-where until the 1950s livelihoods centered on fishing and minor agricultural activities — and the increasing exposure to hydrogeological risks made Polesine an "area to escape from," according to sociologists who studied the substantial outmigration from the area to the industrial cities of Northern Italy in the 1950s-1960s. ${ }^{40}$ In an effort 
to address the poverty, various local economic development programs have been promoted since the 1970s. ${ }^{41}$ The placement of the power station of Porto Tolle in such an area was part of a political effort to bring employment opportunities to a place where there were few.

At the time of the conception of the Porto Tolle power station, the surrounding territory between Porto Marghera in the Veneto region and Ravenna in the Emilia Romagna region had already become established as part of the so-called "petrochemical quadrilateral" of the Po River valley, the multipolar industrial area extending also to Mantua in the Lombardy region and Ferrara in the Emilia Romagna region. ${ }^{42}$ The petrochemical industry, which mostly specialized in the production of plastics and fertilizers for agriculture, depended on the refining of crude oil for energy and raw material. The "petrochemical quadrilateral" was highly interconnected by land and sea infrastructures (pipelines, roads, railways, barges, etc.) intended to facilitate the flow of oil and chemical products. The location of the Porto Tolle oil-fueled power station was chosen by Enel for a variety of reasons, including the possibilities for the oil to be stored, refined, and transported by the infrastructures of the "petrochemical quadrilateral."

Since the conception of the power station of Porto Tolle and the introduction of intensive agricultural activities based on the use of chemical fertilizers in the early 1970s, the landscape of water, land, oil, and gas in the Po River delta has been the object of a contentious process of economic development and environmental protection. As documented on film, recorded at the time of its construction, the population of Porto Tolle was aware of the environmental threats caused by a thermoelectric power station fueled by oil, but many accepted it because of the promise of jobs. ${ }^{43}$ As a man declared in an interview filmed in 1976, "It's better to die from smog in our land, in our Delta, rather than in Milan.",44

At the time of the construction of the power station (Figure 14.10), only a few groups contested the possible impacts of the new development measures on the fragile and marshy landscape of the Po Delta, which was home to a wide variety of animal species. ${ }^{45}$ Local environmentalists advocated for environmental protection and obtained the creation of the Bocche di Po regional natural reserve (1977), still considered one of the areas of greatest avifaunal interest in Italy. ${ }^{46}$ Despite the environmental concerns, economic and logistical reasons led the transformation of the area. In addition to generating employment, the power
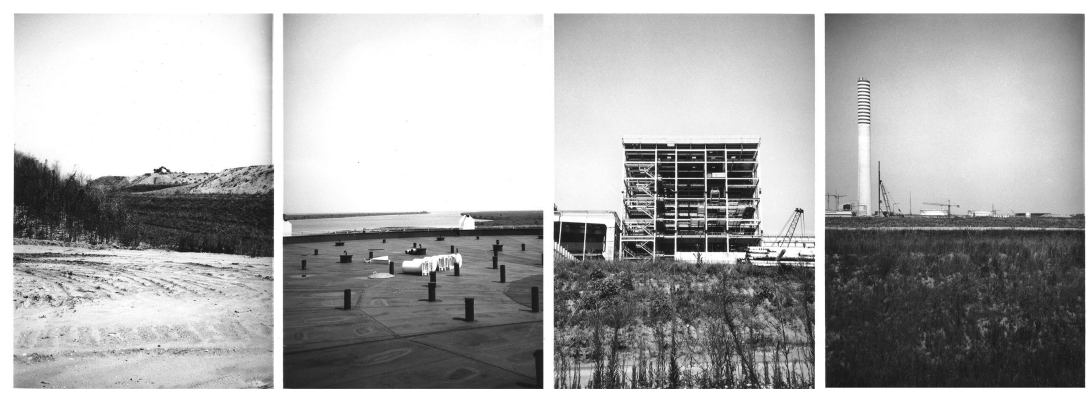

FIGURE 14.10 Photographs taken during the construction of the Porto Tolle power station: (a) transport of sand to the southern part of the site, aimed at preparing the ground of the future oil depots; (b) an oil depot in the northern area of the site and the Po River entering the Adriatic Sea; (c) the machinery hall and the boilers; and (d) the chimney, oil depots, and piling rigs. Source: Vinicio Zanardi. 
station's location was convenient for the Enel company, since the site had access to both sea and river water to cool the plants and it could be easily connected to oil depots in Ravenna or in Porto Marghera. ${ }^{47}$ Moreover, the Porto Tolle power station could use 800,000 tons of oil that Ravenna's refinery (owned by Sarom) would produce over the following decade, at a time when it was at risk of closure. ${ }^{48}$

Environmental conflicts intensified at the end of the 1980s, when the emissions of the power station attracted the attention of some local residents. Following various struggles, the process of environmental protection that started at the end of the 1970s continued with the creation of two Po River delta regional parks (in Emilia Romagna in 1988 and in Veneto in 1997), one of which was included in 1999 on the list of UNESCO sites, and several areas received recognition as Sites of Community Importance (SIC) and Special Protection Areas (ZPS) in the framework of the EU's Natura $2000 .{ }^{49}$ At that time, the protected areas were becoming part of a natural heritage, from which any form of economic exploitation of water, land, oil, or gas was prohibited.

The beginning of the new millennium saw a simultaneous resurgence of environmental activism and economic development initiatives related to oil and gas in Polesine. While environmentalists were working to protect local ecosystems from various threats, ${ }^{50}$ Enel was proposing to convert the oil-fueled Porto Tolle power station to coal. Edison was creating a new power energy plant fueled by gas ${ }^{51}$ a few kilometers away from the Enel power station, and a joint venture by Exxon Mobil, Qatar Terminal Limited, and Snam was starting the first Italian offshore LNG regasification plant in the Adriatic Sea. ${ }^{52}$ Following the release of data about the exceptional rate of cancer, respiratory, and cardiovascular diseases registered in Polesine ${ }^{53}$ the struggle against Enel's proposal to convert to coal the Porto Tolle plant intensified. In 2013, the project was rejected by local and national authorities, and in 2014 the former chief executive officers of Enel were sentenced and later released for the crime of "threat of sanitary disaster." 54

A new phase in the life of the Po River delta started in 2015, after the closure of the power station, when the delta was listed as a UNESCO Biosphere Reserve. In the same year, a team coordinated by the Consortium for the Land Reclamation of the Po River Delta (Consorzio di Bonifica Delta del Po) started working for the inclusion of Polesine among the marginal areas eligible to receive funds from the National Strategy for the Development of Inner Peripheries (SNAI, Strategia Nazionale per le Aree Interne 2014-2020). ${ }^{55}$ In 2018, SNAI funded a local development program (Contratto di Foce Delta del Po) working to enhance local heritage related to water and to promote slow tourism in the area ${ }^{56}$ After several contentious decades, the program seems to be trying to reconcile environmental protection and economic development in Polesine, even though the environmental impact of the gas industry in the area is still being researched.

\section{The Porto Tolle Power Station as Heritage}

The power station of Porto Tolle is one of several large thermoelectric plants constructed in Italy in the final decades of the twentieth century. Earlier hydroelectric and thermoelectric plants had often been designed by well-known architects and engineers. But Porto Tolle was built during a period when, as Rosario Pavia notes, less attention was paid to design and plants were increasingly imagined as detached from their territories. ${ }^{57}$ The plants built at this time nevertheless include noteworthy spaces, architecture, and environments that 
can be profitably enhanced through regeneration projects. Thermoelectric plants, including oil-fueled ones, can represent heritage for the future, a sign of recent history and fossil fuel-dependent energy production. Porto Tolle, formerly one of the most important plants nationally and located in a unique and fragile environment, can become part of the petroleumscape heritage of tomorrow.

In this section, we consider how this power plant might find a new role in connection with its territory and which elements might be profitably enhanced in a process of regeneration. We also consider how the petroleumscape it belonged to could be made apparent, thereby cultivating knowledge and awareness.

One way the Porto Tolle power plant has the potential to find new meaning is in relation to its biodiverse territory. The Po River delta offers new possible relationships in terms of sustainable tourism and slow mobility. Indeed, the site could belong to a network of bike paths and boat tours exploring the delta and its nature, avifauna, aquaculture, and fishing activities as well as its historic buildings like palaces or casoni and the decommissioned drainage pump structure that today hosts the Museo della Bonifica di Ca' Vendramin (the drainage museum, part of a global network of water museums), but also structures like the abandoned methane wells. A regeneration project could take advantage of the unspoiled beaches, marshes, and bodies of water located within or right next to the power stations. The Enel site hosts not only the power station (the plant's surface covers about 200 ha out of 380 ha) but also a plant nursery, wetlands, a canal, a small woodland as well as areas overtaken by spontaneous vegetation. These could become part of a connected system, integrated with the surroundings. Several oil-related structures could also be enhanced and reused, avoiding a tabula rasa approach and educating visitors about the wider petroleumscape.

The petroleumscape of the power station, which ran on heavy fuel oil, includes the aforementioned $92 \mathrm{~km}$-long oil pipeline that linked the plant to the Integrated Fuel and Oil Pipelines Plant depot (IICO-Impianto Integrato Combustibili e Oleodotti) in Ravenna. Fuel destined for Porto Tolle was carried to the IICO depot via an oil pipeline connected to a sea terminal, to which Panamax delivered fuel imported mainly from Libya and to a lesser extent, from other Middle Eastern countries as well as from the North Sea, Russia, Brazil, and the US. ${ }^{58}$ These connections remind us of the global relationships behind power stations and extraction sites. In case of emergency, the oil would instead be carried by tanker trucks or barges traveling along the Po River from the power stations of Sermide and Ostiglia (formerly owned by Enel), ${ }^{59}$ in the province of Mantua, about $120-130 \mathrm{~km}$ from Porto Tolle. In the past, before the pipeline had begun operating, oil was also delivered from Marghera via barges or tanker trucks (Figures 14.11-14.12). These oil infrastructure and transport systems connecting to the Porto Tolle plant are mainly out of sight, underground, under or on water, far from inhabited areas.

Despite being in a remote area, the power station has a strong physical presence. A visitor would notice the $250 \mathrm{~m}$ high chimney from afar, as it stands out on the horizon of the Po River delta, as well as the electric trellis and cables, both of which are material signs of the conversion from oil to electricity. Drawing nearer, one notices the large machinery hall, its four high boilers, and to a lesser extent, the oil tanks (present in two areas) (Figure 14.13). Once inside the Enel site, one sees the electric stations (Figure 14.14), depots, complementary plants (e.g., for the treatment of process waters and of wastewater), pipes, offices, an information area, the "natural" areas, and elements of the plant cooling system, particularly two canals. The water was collected both from the river (Po di Pila) via a canal and in 


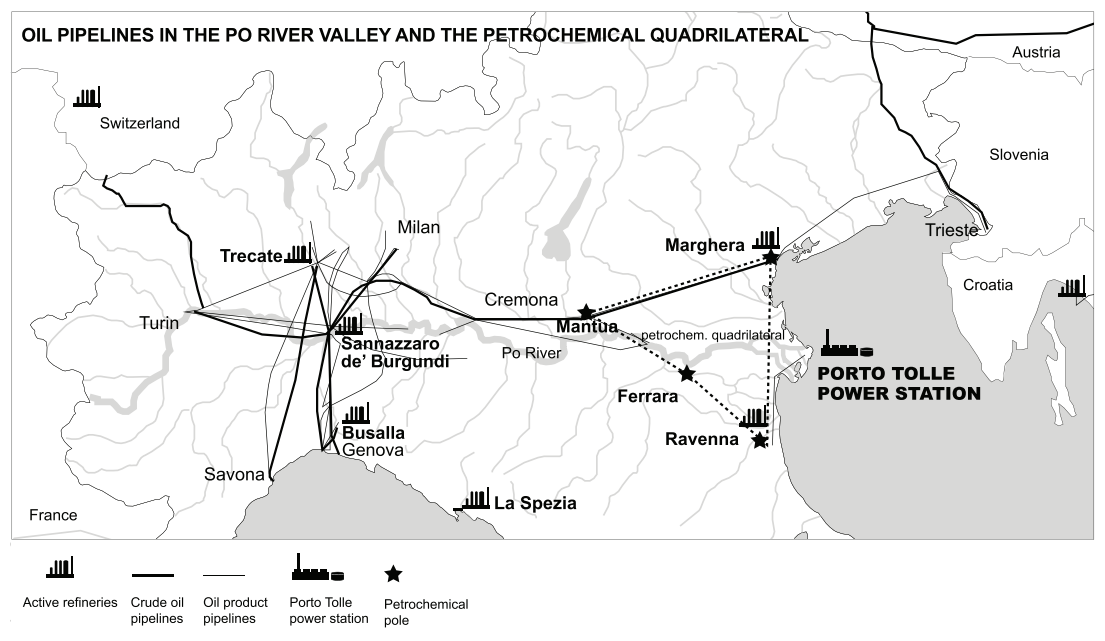

FIGURE 14.11 Oil pipelines in the Po River valley, the "petrochemical quadrilateral," and the location of the Porto Tolle power station. Source: Chiara Geroldi. Pipelines base map information: (C) PLATTS for the underlying grids for electricity, gas, and oil, 2016 C European Union, 2019.

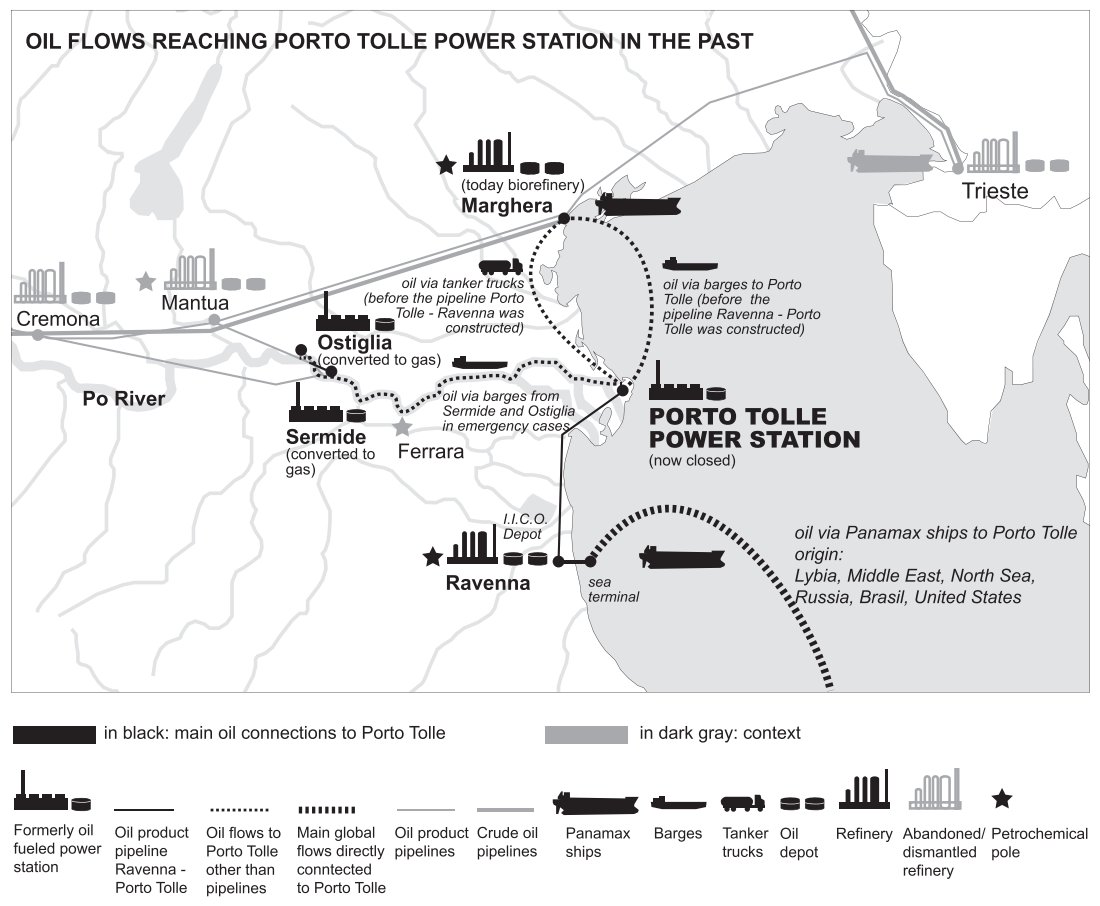

FIGURE 14.12 Oil flows reaching the Porto Tolle power station in the past and the pipeline and refinery system present in the territory. Source: Chiara Geroldi. Pipelines base map information: (C) PLATTS for the underlying grids for electricity, gas, and oil, 2016 (C) European Union, 2019. 


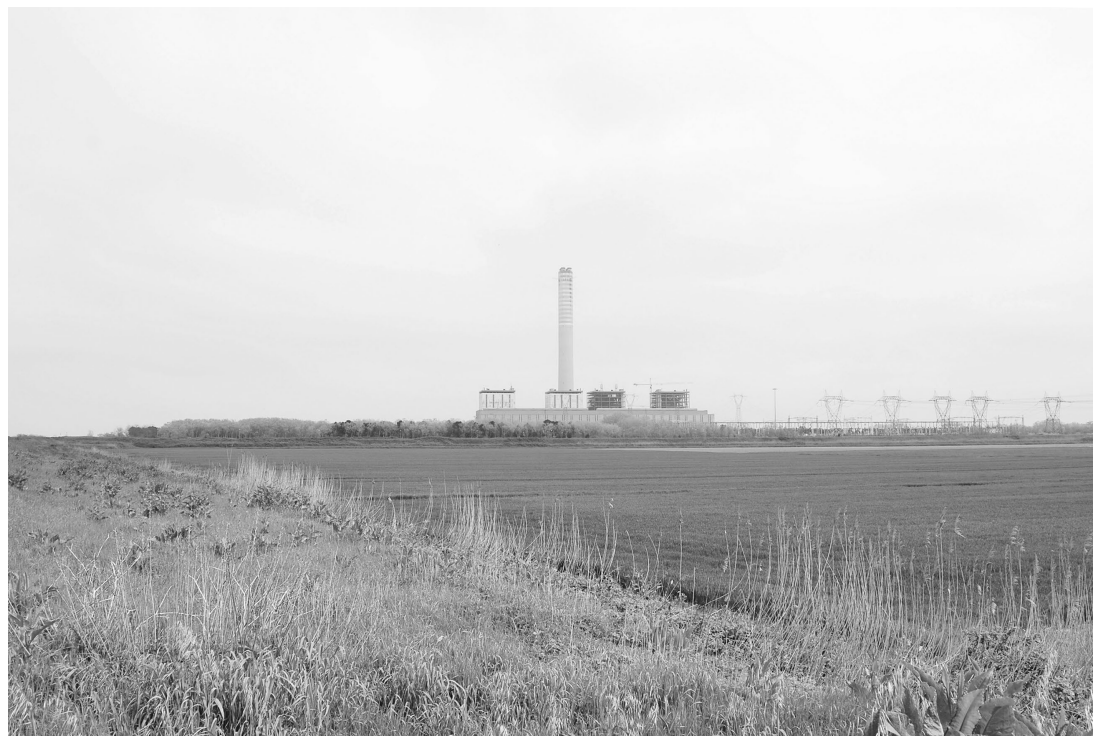

FIGURE 14.13 Porto Tolle power station. Source: Chiara Geroldi.

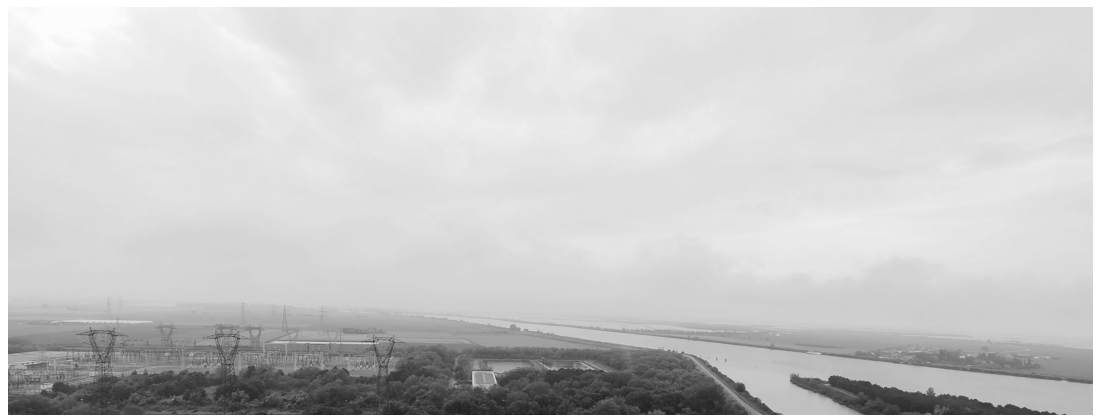

FIGURE 14.14 Electric station and system of pylons extending from the power station. Source: Chiara Geroldi and Gloria Pessina.

periods of low water, from the sea via a canal in the Sacca del Canarin. After the cooling, water was then returned through a gate system with two canal branches leading back to its origin (river or sea). The plants are built on a raised pile foundation ( $3 \mathrm{~m}$ a.s.1.) with embankments for additional flood protection ( $4.5 \mathrm{~m}$ a.s.1.). ${ }^{60}$

Specific elements of the plant are part of the fuel system. The oil tanks, surrounded by earthen embankments and located at the north and south sides of the plant area (two of 50,000 $\mathrm{m}^{3}$ and one of $100,000 \mathrm{~m}^{3}$ in the north, six of $100,000 \mathrm{~m}^{3}$ in the south, two of which have been dismantled), occupy, respectively, about 8 and 23 ha. The capacity of these tanks ensured steady production at the power station in case of oil delivery problems. ${ }^{61}$ The tanks have a floating roof and external stairs to access the top and to walk on the upper rim (Figure 14.15). Beyond the tanks and other main parts of the plant (e.g., machinery hall and boilers), other elements related to the fuel system include the oil pipeline input, the dock (Figure 14.16), an 


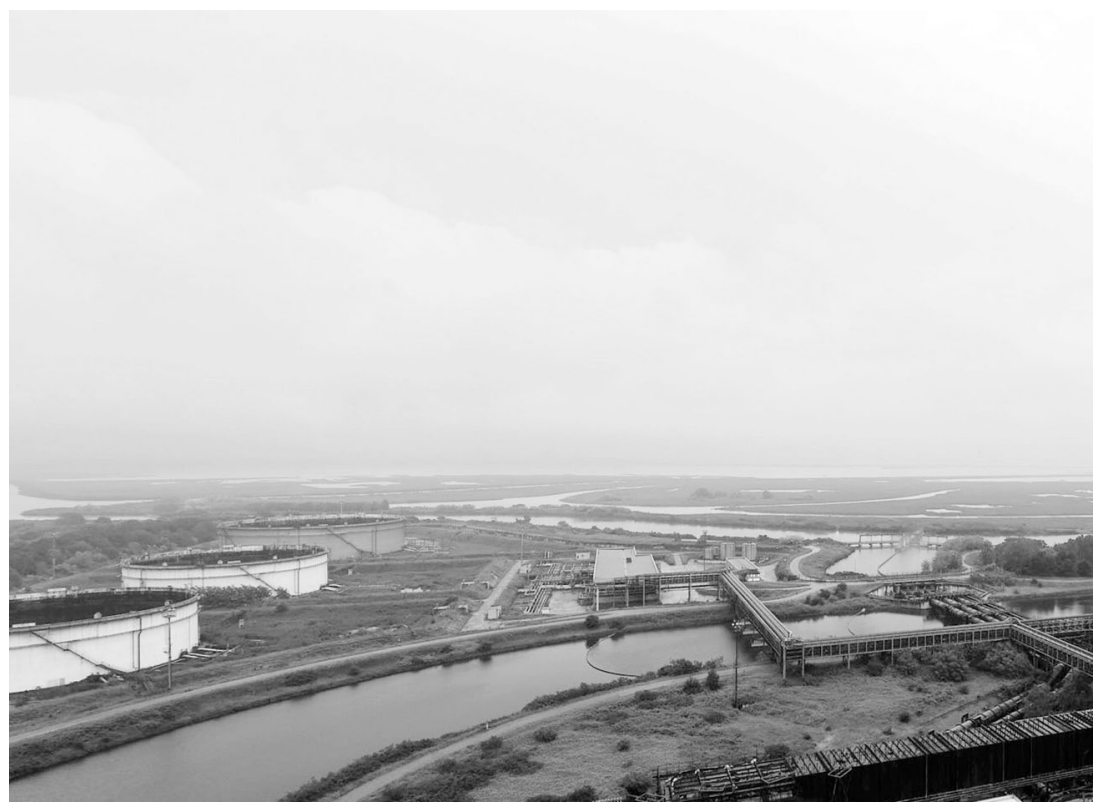

FIGURE 14.15 Oil tanks and view of the two canals used for plant cooling. Source: Chiara Geroldi.

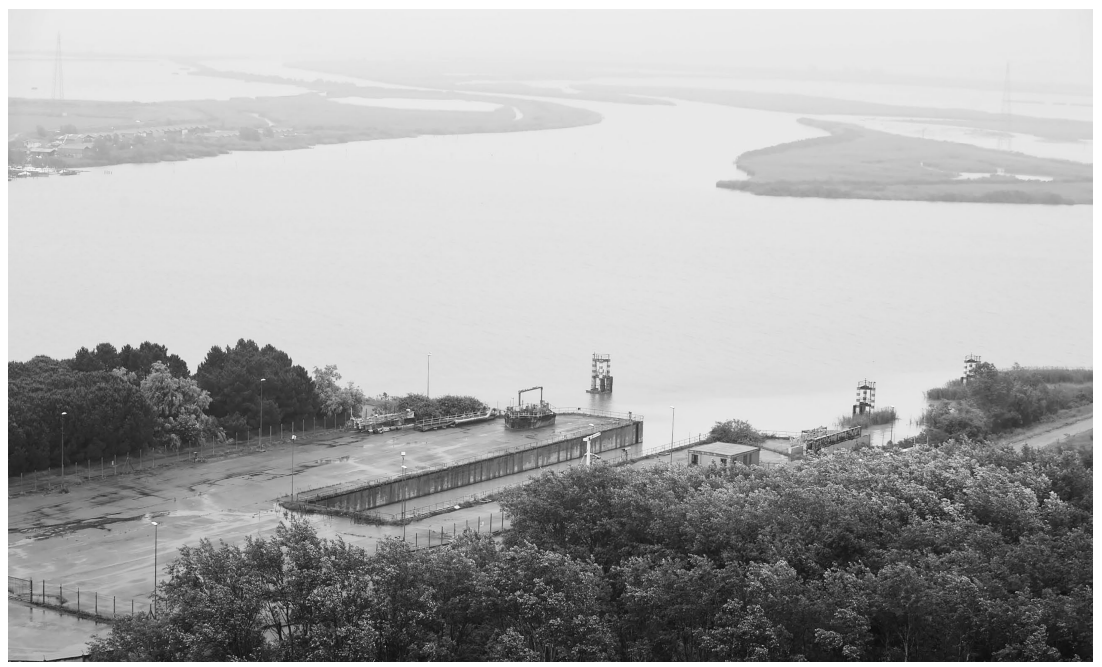

FIGURE 14.16 The dock for barge unloading. Source: Chiara Geroldi.

alternate pier for unloading barges, a tanker truck unloading area, a pumping station, a system of aboveground oil pipes, two basins for collecting ashes, and a fire prevention system.

This inventory and description of oil-related elements and more general artifacts of thermoelectric power stations (Figure 14.17) indicates the variety of components one might find in a landscape of oil as well as the architectural/spatial value of the different elements. Such information is useful when discerning what is worth maintaining as heritage. By tracing the 


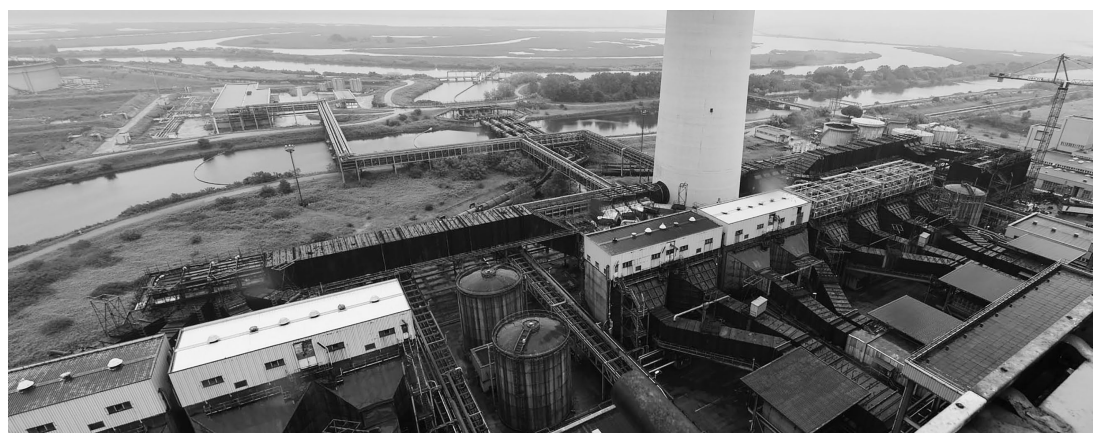

FIGURE 14.17 Intricate system of tubes and pipes in the proximity of the chimney. Source: Chiara Geroldi and Gloria Pessina.

flows of fuel, we can better connect this site to both worldwide and more local networks of oil, that is, to the petroleumscape. This history of connectedness should be taken into consideration, conveyed, and enhanced. One possibility is to collect and display documentary evidence, photographs, and archival materials, and to construct maps of the previous flows and existing structures as well as to design informative devices or specific design installations related to this history to be located in the territory and at the plant. ${ }^{62}$

Our description of the oil flows and power station elements undertaken also represents a way to maintain and transmit the history of these structures and the roles they have played. The power station of Porto Tolle contains elements of the petroleumscape that could be maintained and reused-as architecture and to convey the history of the site. In particular, the concrete chimney could become a very high lookout point, and the large machinery hall and the boiler structures could easily host a variety of uses. Some of the oil tanks could be reused, for instance, for sports. The docks for unloading barges could be used by boat tours. The artificial canals constructed to take and return water represent human interventions that impacted the local ecology and will need to be reinterpreted. The embankments of the power station represent a specific part of the history of the anthropogenic operations that have constructed the modern delta. They could be enhanced as slow mobility paths, with connections between the site and the broader territory. The terrestrial and aquatic "natural" areas, the embankments, canal system, and structures could thus find new meanings and uses in a close relationship with the unique territory of the Po River delta.

\section{Conclusion}

As research consultants for Enel, when we started to analyze the territories and the architecture of ten thermoelectric power stations in Italy included in the Futur-e project, we entered an area given little attention in urban, landscape, and architecture scholarship. Focusing on the requests of the company, we initially strived to provide detailed descriptions of the plants and their contexts, in order to give adequate information to those who might respond to the project's call for ideas and manifestations of interest. In the course of the work, we realized that our studies and our observations of the plants' territories provided a helpful starting point for further research. As a result, we started to explore various theoretical approaches that might help us interpret the phenomena, the territories, the landscapes, and the architecture. Starting by addressing the topic from our previous knowledge of 
planetary urbanization, landscape architecture, and political ecology, we encountered the literature on the petroleumscape, which is represented in its variety and complexity in the book you are currently reading.

This chapter considers oil-fueled thermoelectric power stations as among the "global landscapes of oil." It could be easy to overlook these power stations' role in the petroleumscape, because they produced electricity. But like so much else, they were fueled by oil and would not have existed without it. The station we have been discussing in the most detail, Porto Tolle, is located in a particularly unpopulated and environmentally fragile landscape characterized by interaction between land, water, oil, and gas and by contentious processes of development and heritigization that started in the 1970s. In the course of time, the Porto Tolle power station became integrated in the network of infrastructures of the "petrochemical quadrilateral" 63 and firmly attached to the destiny of the whole territory, despite its seemingly marginal position. Hence, while reflecting on the past and on possible futures for this tiny example of the "global landscapes of oil," we have had to consider the destiny of the larger territory.

Today, the four poles of the quadrilateral lie in a state of partial abandonment and severe pollution, still characterized by the some of the activities of the main refineries (Marghera and Ravenna), in line with the claim that "old refineries rarely die." 64 The related chemical plants are also partially active, but several oil-related infrastructures have ceased their operations. Although the industrial poles of Marghera, Ravenna, Mantua, and Ferrara have been classified as contaminated Sites of National Interest, ${ }^{65}$ eligible for special national depollution plans, the major petrochemical companies often did not comply with their obligation to decontaminate the sites ${ }^{66}$ and managed to sell them to large companies active in the field of logistics. ${ }^{67}$

Ironically, such highly polluted compounds are located at the outskirts of four of the most important UNESCO sites of Italy: "Venice and its lagoon," "Ferrara, city of the Renaissance and its Po Delta," "Mantua and Sabbioneta," and "Early Christian Monuments of Ravenna." 68 Located in a less populated area, surrounded by a landscape characterized by exceptional environmental qualities, and recognized as a UNESCO Biosphere Reserve, the Porto Tolle power station allows us to observe in depth the main features of a portion of the Po River valley as part of a "palimpsestic global petroleumscape." ${ }^{\prime \prime 9}$ It also enables us to imagine a future in which we can rebalance the broken equilibrium between land, water, and oil and overcome outdated and harmful economic development models.

Contributions: The two authors jointly conceived the structure of this chapter and finalized the entire piece. Chiara Geroldi authored the first, third, and fifth sections and Gloria Pessina authored the second, fourth, and sixth sections. The authors wrote the introduction together. The work of Chiara Geroldi is supported by the Department of Architecture and Urban Studies (DAStU) at Politecnico di Milano, while Gloria Pessina's research is supported by the Excellence Project Fragilità Territoriali/Territorial Fragilities (2018-2022; financed by the Italian Ministry of University and Research L.232/2016) of the DAStU/ Politecnico di Milano.

\section{Notes}

1 The Politecnico di Milano consultancy research group was coordinated by G. Azzone and A. Balducci. It has included, in different time periods, M. A. Bruzzese, C. Geroldi, G. Pessina, V. Galli (DAStU Dept.), M. Arena, I. Bengo, P. Colzani, L. Dell'Agostino, and S. Ratti (DIG Dept.). 
2 For more information on the plants, see Chiara Geroldi and Gloria Pessina, "Le centrali elettriche coinvolte nel progetto Futur-e," Territorio 86, no. 3 (2018): 72-84, DOI:10.3280/TR2018086011. For the Futur-e project, see https://corporate.enel.it/en/futur-e.

3 Some literature exists on the spatiality of hydroelectric plants and of a variety of energy production plants, for example, Rosario Pavia, ed. Paesaggi elettrici: territori, architetture, culture (Venezia: Enel, Marsilio, 1998); Michael Jakob, ed. Architecture and Energy, 2G n. 18 (Barcelona: Editorial Gustavo Gili, 2001). On thermoelectric plants, see Chiara Geroldi, "Landscapes and Architecture of Thermoelectric Power Stations in Italy," Territorio 86 (2018), DOI:10.3280/TR2018086013. On the petroleumscape, see Carola Hein, "Oil Spaces: The Global Petroleumscape in the Rotterdam/The Hague Area," Journal of Urban History 44, no. 5 (February 2018): 887-929, DOI10.1177/0096144217752460.

4 Neil Brenner and Christian Schmid, "Planetary Urbanization," in Urban Constellations, ed. Matthew Gandy (Berlin: Jovis, 2012), 11-13.

5 Neil Brenner, "Urban Theory Without an Outside," in Implosions/Explosions: Towards a Study of Planetary Urbanization (Berlin: JOVIS, 2014), 14-35.

6 Brenner and Schmid, "Planetary Urbanization."

7 Neil Brenner, "Eight Theses on the Urbanization Question: Introducing the Urban Theory Lab/ GSD," in Instigations Engaging Architecture Landscape and the City, eds. Mohsen Mostafavi and Peter Christensen (Baden: Lars Müller Publishers, 2012), 346-63.

8 Ibid.

9 Carola Hein, "Global Landscapes of Oil," in New Geographies 2: Landscape of Energy, ed. Rania Ghosn (Cambridge: Harvard University Press, 2009).

10 Hein, "Oil Spaces."

11 Matt Huber, "Energy and Social Power. From Political Ecology to the Ecology of Politics," in The Routledge Handbook of Political Ecology, eds. Tom Perreault, Gavin Bridge, and James MacCarthy (Oxon: Routledge, 2015).

12 Michael Watts, "Crude Politics: Life and Death on the Nigerian Oil Fields," Niger Delta Economies of Violence Working Papers, no. 25 (2009): 1-27; Michael Watts, "Antinomies of Community: Some Thoughts on Geography, Resources and Empire," Transactions of the Institute of British Geographers 29, no. 2 (2004); Michael Watts, "Oil-City: Petro-Landscapes and Sustainable Futures," in Ecological Urbanism, eds. Gareth Doherty and Mohsen Mostafavi (Baden: Lars Müller Publishers, 2010), 96.

13 Watts, "Oil-City," 97.

14 Karen Bakker and Gavin Bridge, "Material Worlds? Resource Geographies and the "Matter of Nature'," Progress in Human Geography 30, no. 1 (2006): 5-27.

15 On the material forms of oil, see Gavin Bridge, "Past Peak Oil: Political Economy of Energy Crises," in Global Political Ecology, eds. Richard Peet, Paul Robbins, and Michael J. Watts (London: Routledge, 2011), 316. On extractive spaces, see Gavin Bridge, "The Hole World: Scales and Spaces of Extraction," in New Geographies 2: Landscape of Energy, ed. Rania Ghosn (Cambridge: Harvard University Press, 2009), 46-47.

16 Hein, "Global Landscapes of Oil."

17 Carola Hein, "Port Cities: Nodes in the Global Petroleumscape between Sea and Land," Technosphere Magazine, 2017 [online publication].

18 Hein, "Oil Spaces," 888.

19 Ibid., 33, 42.

20 Stu Daultrey, "The Political Ecology of Nuclear Power in Ireland or, How Nuclear Wastes," Antipode 12, no. 1 (June 1980): 108-11, https://doi.org/10.1111/j.1467-8330.1980.tb00310.x

21 Karen Bakker, "The Politics of Hydropower: Developing the Mekong," Political Geography 18, no. 2 (February 1999): 209-32; Maria Kaika, "Landscapes of Energy: Hydro-Power from TechnoNatures to Retro-Natures," in New Geographies 2: Landscape of Energy, ed. Rania Ghosn (Cambridge: Harvard University Press, 2009), 103-10; Michael Webber, "The Political Economy of the Three Gorges Project," Geographical Research 50, no. 2 (May 2012): 154-165, https://doi. org/10.1111/j.1745-5871.2011.00725.x

22 See Gloria Pessina, "Nodi da sciogliere nello spazio dei flussi. Vita nei territori delle centrali elettriche del progetto Futur-e," Territorio, 86 (2018), DOI:10.3280/TR2018-086014, for an initial contribution on these topics.

23 Geroldi, "Thermoelectric Power Stations."

24 Enel S.p.A. b, “The Project," https://www.enel.it/en/futur-e/a201611-the-project.html, accessed April 28, 2017. 
25 Giuseppe D'Orsi, “La riqualificazione delle centrali Enel: l'esempio del Progetto Futur-e," Energia, ambiente e innovazione, no. 2 (April-June 2018): 30-34, DOI:10.12910/EAI2018-031.

26 Enel S.p.A. b, "The Project."

27 Pessina, "Nodi da sciogliere nello spazio dei flussi. Vita nei territori delle centrali elettriche del progetto Futur-e," 106.

28 For data and information on the four plants, see Geroldi and Pessina, "Le centrali elettriche coinvolte nel progetto Futur-e."

29 Comune di Civitavecchia, Piano di Emergenza Comunale, 2016, 28.

30 MWH S.p.A., "Centrale Termoelettrica di Rossano Relazione di Riferimento ai sensi del DM 272/2014 Enel Produzione S.p.A,” December 2015, 10, 11.

31 Ibid.

32 For more physical descriptions, see Geroldi, "Thermoelectric Power Stations."

33 For more design reflections, see Ibid.

34 Elio Migliorini and Mario Brunetti, "Polesine," in Enciclopedia Italiana di Scienze, Lettere e Arti (Roma: Treccani, 1935), http://www.treccani.it/enciclopedia/polesine_\%28EnciclopediaItaliana\%29/.

35 Catherine Dezio, Bruna Vendemmia, Giulia Setti, Domenico D’Uva, Fabio Lepratto, Lavinia Dondi, Nicole De Togni, et al. "Territorial Fragilities in Italy. Defining a Common Lexicon," Territorio, 91 (2019).

36 Giorgio Osti, “Un'economia leggera per aree fragili: criteri per la sostenibilità ambientale del Nord Italia," Sviluppo Locale 27 (2004-2005): 9-31; Enrico Anguillari, “Abitare territori fragili. Il caso del delta del Po descritto dagli amministratori locali," Archivio di Studi Urbani e Regionali, 97-98 (2010): 261-81, DOI: 10.3280/ASUR2010-097015; Marina Bertoncin, Logiche di terra e acqua. Le geografie incerte del delta del Po (Verona: Cierre, 2004).

37 Tiziana Quaglia, Francesco Musco, and Graziano Caramori, eds. Aree protette e sviluppo sostenibile. Un piano per la conservazione della biodiversità e lo sviluppo dell'economia locale nel delta del Po (Venezia: Regione Veneto, 2011): 29-30.

38 Pietro Caloi, "How Nature Reacts to Human Interventions. Responsibilities of Those Who Cause and Who Interpret Such Reactions," Gli Annali di Geofisica, Istituto Nazionale di Geofisica e Vulcanologia, no. 23 (1970): 283-305.

39 Caloi, "How Nature Reacts."

40 Achille Ardigò, “Il Polesine, un'area di fuga nell'Italia settentrionale," in Il Polesine, ed. Centro Nazionale di Prevenzione e Difesa Sociale (Milano: Edizioni di Comunità, 1964), 97-142.

41 Ministro dell'Interno, "Decreto Costitutivo del Consorzio per lo sviluppo economico e sociale del Polesine," n. 2050.15.100.128, February 19, 1963; Consiglio Regionale del Veneto, "Interventi a favore dei consorzi tra enti locali per la realizzazione dei piani di cui all'art. 27 della legge 22 ottobre 1971 n. 865," Regional Law, April 22, 1977, n. 3 (BUR n.18/1977).

42 Diego Marazza, "Il quadrilatero del petrolchimico in Pianura Padana," Ecoscienza 4 (2016): 58.

43 VittorioMarchetti, “Cittàecampagna.Venezia,MargheraeilDeltadelPo,”videodocumentary, 43:33 (1976), http://www.teche.rai.it/1976/03/citta-e-campagna-venezia-marghera-e-il-delta-del-po/.

44 Marchetti, "Città e campagna."

45 Quaglia, Musco, and Caramori, Aree protette, 19.

46 PPRA, Relazione Illustrativa. Piano Paesaggistico Regionale d'Ambito Arco Costiero Adriatico Laguna di Venezia Delta del Po (Venezia: Regione Veneto e MiBACT, 2015): 131.

47 Roberto Bianchin, "Si fermerà tra una settimana la centrale delle polemiche," La Repubblica, October 18, 1984, http://ricerca.repubblica.it/repubblica/archivio/repubblica/1984/10/18/ si-fermera-tra-una-settimana-la-centrale.html.

48 "Polemiche a Ravenna sulla raffineria AGIP," La Repubblica (February 27, 1985), http://ricerca. repubblica.it/repubblica/archivio/repubblica/1985/02/27/polemiche-ravenna-sulla-raffineriaagip.html.

49 Quaglia, Musco, and Caromori, Aree protette, 20.

50 Giovanni Carrosio, "Ingiustizia ambientale nel bacino del Po: il conflitto tra il Polesine e la città di Milano per l'inquinamento delle acque," Partecipazione e conflitto 6, no. 1 (2013), https://doi. org/10.3280/PACO2013-001005.

51 Giorgio Osti, "Dalla terra al mare. Esperti e istituzioni nella realizzazione di una grande infrastruttura Energetica," in I conflitti ambientali. Esperti, politica, istituzioni nelle controversie ecologiche, ed. Luigi Pellizzoni (Bologna: il Mulino, 2011).

52 Osti, "Dalla terra al mare." 
53 Paola Zambon, ed., “Analisi dell'incidenza dei tumori nell'ASL 19 di Adria,” Istituto Oncologico Veneto, IRCCS Registro Tumori del Veneto (Padova: Regione del Veneto, 2008).

54 Alexander H. Bell, "Il processo alla centrale termoelettrica di Porto Tolle: gli ex Amministratori Delegati di Enel condannati per pericolo di disastro sanitario," Tribunale di Rovigo, March 31, 2014, https://archiviodpc.dirittopenaleuomo.org/d/3355-il-processo-alla-centraletermoelettrica-di-porto-tolle-gli-ex-amministratori-delegati-di-enel-cond;GiuseppeFornariand Enrico di Fiorino, "Emissioni nocive dalla centrale di Porto Tolle: la cassazione mette la parola fine," Cassazione Penale, Sez. I, January 19, 2018 (ud. January 10, 2018), n. 2209, https://www. giurisprudenzapenale.com/2018/04/04/emissioni-nocive-dalla-centrale-di-porto-tolle-lacassazione-mette-la-parola-fine/.

55 https://www.agenziacoesione.gov.it/lacoesione/le-politiche-di-coesione-in-italia-2014-2020/ strategie-delle-politiche-di-coesione/strategia-nazionale-per-le-aree-interne/.

56 http://contrattodifocedeltadelpo.it.

57 Pavia, Paesaggi elettrici.

58 Enel S.p.A., written communication with the authors, May 4, 2017.

59 Ibid.

60 Enel S.p.A. a. Centrale Termoelettrica di Porto Tolle, printed booklet retrieved at the Porto Tolle plant.

61 Ibid.

62 For similar arguments in a context of a coal-fuel power station see Geroldi, "Landscapes and Architecture of Thermoelectric Power Stations in Italy."

63 Marazza, "Il quadrilatero del petrolchimico in Pianura Padana," 58-59.

64 Carola Hein, "'Old Refineries Rarely Die': Port City Refineries as Key Nodes in the Global Petroleumscape," Canadian Journal of History/Annales canadiennes d'histoire, 53, no. 3 (2018): 450-79, https://doi.org/10.3138/cjh.ach.53.3.05.

65 "Contaminated sites of national interest (SIN)," ISPRA, n.d., https://www.isprambiente. gov.it/en/activities/soil-and-territory/copy_of_contaminated-sites/contaminated-sites-ofnational-interest-sin.

66 Commissione Parlamentare d'Inchiesta sulle attività illecite connesse al ciclo di rifiuti e su illeciti ambientali ad esse correlati, "Relazione sulla situazione delle bonifiche dei poli chimici: il "Quadrilatero del Nord» (Venezia-Porto Marghera, Mantova, Ferrara, Ravenna),” Doc. XXIII, n. 11, Camera dei Deputati, Senato della Repubblica Italiana.

67 Gilda Zazzara, "I cento anni di Porto Marghera (1917-2017)".

68 UNESCO - World Heritage Centre, "Properties inscribed in World Heritage List," http://whc. unesco.org/en/statesparties/IT.

69 Hein, "Palimpsestic Petroleumscape." 